\title{
Phaeton's Flight, Adonis's Trial, and Minerva in the House of Envy: Lodovico Dolce between Ovid and Ariosto
}

\author{
ANDREA TORRE ${ }^{1}$
}

Scuola Normale Superiore di Pisa

\begin{abstract}
Introducing Thyeste: Tragedia da Seneca (1547), the Venetian writer Lodovico Dolce (1508-68) defines the art of translating a book as an experience that lives in the "perspective of the becoming [...] because in order to translate, it is necessary for us to take another language or (if possible) another human nature." This article presents three case studies where the nexus between Ludovico Ariosto's Ovidianism and Dolce's Ariostism becomes an example of the stylistic and editorial relationship between word and image, as well as a paradigmatic explanation of the dynamics and strategies of reception in the early age of print. The aims of this exercise are the following: (1) to investigate the important mediation of Ariosto's epic-chivalric model for the translation of the classics into vernacular and for the "canonization" of texts through their publication; (2) to study the man-to-man combat between Dolce's writing, Ariosto's pattern, and Ovid's Metamorphoses, and the way it develops from the Stanze nella favola di Venere e Adone (1545) to the thirty cantos of the poem Le Trasformazioni (155 3); (3) to analyze the history of the illustrations in Ariosto's Cinque canti from the perspective of the interaction between words and images, modes of writing and reading, and modes of invention and reception.
\end{abstract}

En présentant Thyeste. A tragedy from Seneca (1547), l'écrivain vénitien Lodovico Dolce (15081568) définit l'art de traduire un ouvrage comme une expérience de transformation puisque traduire implique d'adopter une autre langue, voire (si possible) une autre nature humaine. Cet article présente trois études de cas dans lesquelles la juxtaposition de l'ovidisme de L'Arioste et de l'ariostisme de Dolce devient l'exemple d'une relation stylistique et éditoriale entre le mot et l'image, ainsi qu'un cadre paradigmatique pour comprendre les dynamiques et les stratégies de la réception durant les débuts de l'imprimerie. Cette étude a trois objectifs : 1) explorer l'importance du modèle épique et chevaleresque de L'Arioste pour la traduction des classiques en langue vernaculaire et pour la " canonisation» de ces ouvres par leur publication; 2) examiner le combat au corps entre l'écriture de Dolce, le modèle de L'Arioste et les Métamorphoses d'Ovide, ainsi que le développement menant des Stanze nella favola di Venere e Adone (1545) aux trente chants du poème Le Trasformazioni (1553) ; 3) analyser l'histoire des illustrations des Cinquecantide L'Arioste du point de vue de l'interaction entre mots et images, des modes d'écriture et lecture, ainsi que des modes d'invention et de réception.

1. The research leading to these results has received funding from the European Research Council under the European Community's Seventh Framework Programme (FP7/2007-2013) / ERC Grant Agreement n. 295620: ERC Advanced Grant 2011, "LOOKINGATWORDS: Looking at Words through Images: Some Case Studies for a Visual History of Italian Literature." 
"Egli è ingenioso nelle inventioni, nelle dispositioni ordinato, puro e terso nel verso, dolce et elegante nella lingua, grave nelle sententie, mirabilissimo finalmente a dipingerti una cosa dinanzi gli occhi, in tanto che il più delle volte mi par non di legger ma di veder manifestamente quello di che egli tratta." 2

( $\mathrm{He}$ is ingenious in his inventions, orderly in his dispositions, pure and terse in his verse, sweet and elegant in his language, solemn in his sentences, and, finally, highly to be admired in painting something in front of your eyes so that, the majority of times, you think you are not reading but actually seeing what he is dealing with.)

\section{Le Trasformazioni}

D uring the sixteenth century Ovid's Metamorphoses and Ariosto's Orlando furioso ran a parallel course. In the Renaissance debate on the literary genres - as Daniel Javitch stated-the Ovidian pattern becomes a privileged auctoritas in order to dignify the features of the romance and to defend them from the accusation of being a failed classic epic: ${ }^{3}$ from the narrative intricacies and mythopoesis of Metamorphoses, Ariosto learned to weave his own masterpiece of literary realities. At the same time, the Orlando furioso became a lens through which Ovid's poem was to be read. Everyone who translated the Metamorphoses into vernacular referred back to the linguistic, stylistic, and publishing pattern of Ariosto's poem. In 1522 in Venice we see the publication of Nicolò degli Agostini's Tutti gli libri de Ovidio Metamorphoseos; the publisher, Nicolò Zoppino, offers this book with a packaging similar to the one he will later use for the first complete illustrated edition of the Furioso in forty-six cantos (1536; in 1530 Zoppino printed an illustrated edition of the forty-canto version). In 1584, Venetian printers published both the last original

2. Lodovico Dolce, “Apologia contro i detrattori dell'Ariosto," in Ludovico Ariosto, Orlando furioso (Venice: Appresso Mapheo Pasini \& Francesco di Alessandro Bindoni, 1535), sign. Iiiiir. All translations are my own, unless otherwise indicated. I have provided translations only for those passages where I wish to underline the meaning and not for those passages where I am making a linguistic comparison (which comparison would be lost in the translation).

3. See Daniel Javitch, Proclaiming a Classic: The Canonization of Orlando Furioso (Princeton: Princeton University Press, 1991), 71-86. 
illustrated edition of Ariosto's poem and the precious reprint of the Giovanni Andrea dell'Anguillara's Metamorfosi d'Ovidio; the two books present the same typology of iconographic apparatus: we have chalcographic plates that take up the entire page and visualize the entire content of a canto through the laws of perspective. ${ }^{4}$

Lodovico Dolce's Trasformationi appeared between these two dates. ${ }^{5}$ First published in 1553, this work was reprinted six more times by Gabriele Giolito de' Ferrari who, already in his 1551 edition of the Furioso, was informing his readers of the forthcoming publication of a vernacular translation in octaves of Ovid's Metamorphoses:

perché niuna cura è in noi maggior che di giovare alli studiosi delle buone lettere et a gli amatori della lingua volgare, speriamo di darvi similmente fra pochi mesi le dilettevoli Trasformationi d'Ovidio, tradotte dal sovradetto Dolce in questa ottava rima. ${ }^{6}$

(since we have no greater care than to be useful to students of good letters and lovers of the vernacular language, we similarly hope to give you in a few months the pleasant Transformations of Ovid translated by the abovementioned Dolce in such octaves.)

While mentioning "a vernacular translation in octaves," Giolito reveals the literary and publishing project of embodying the formal, thematic, and functional characteristics of the highly esteemed epics of antiquity, especially Ovid's masterpiece, in the Furioso's modern poetry. The elevation of the Furioso to the rank of a classic and the attribution to Ovidian vulgarizations of Ariostan forms and functions that better suit modern times help the Renaissance reader

\footnotetext{
4. On Anguillara’s work see Giacomo Bucchi, "Meraviglioso diletto." La traduzione poetica del Cinquecento e le Metamorfosi d'Ovidio di Giovanni Andrea dell'Anguillara (Pisa: ETS, 2011).

5. On Lodovico Dolce see Ronnie H. Terpening, Lodovico Dolce: Renaissance Man of Letters (Toronto: University of Toronto Press, 1997); Anne Neuschäfer, Lodovico Dolce als dramatischer Autor im Venedig des 16. Jahrhunderts (Frankfurt am Mein: Klostermann, 2001); Andrea Torre, "Divenire memoria," in Lodovico Dolce, Dialogo del modo di accrescere e conservar la memoria, ed. Andrea Torre (Pisa: Edizioni della Normale, 2001), ix-lii; Stefano Giazzon, Venezia in coturno: Ludovico Dolce tragediografo (1543-1557) (Rome: Aracne, 2011).
}

6. Ludovico Ariosto, Orlando furioso (Venice: Giolito, 1551), 255v. 
of Dolce's Trasformazioni to accept without any difficulties the anachronism of the quotes of modern characters - such as Orlando, Marfisa, and Bradamantein the Ovidian mythological stories: e.g., "Mentre [Cadmo] serba la via, ch'al fonte viene, / Ne l'altro canto ad ascoltar v'aspetto / Nel qual io vi verrò forse contando / Prove, che tal mai ne fece Orlando" (5.82.5-8; While Cadmo keeps the path that leads to the river, I wait for you to listen to me in the next canto where I will perhaps tell you of adventures the likes of which Orlando never had), or "La qual non men gagliarda era che bella, / E forse può agguagliar la fama vostra, / Marfisa e Bradamante, onde si vanta / L'età di Carlo; e detta era Atalanta" (16.24.5-8; She was no less brave than beautiful, and her fame is perhaps comparable to that of Marfisa and Bradamante, celebrated heroines of the age of Carlo; and she was called Atalanta).

Dolce's Trasformazioni has been produced with the same packaging used by Giolito for his fundamental 1542 edition of the Furioso. The artist Giovanni Antonio Rusconi modelled the iconographic apparatus of the Trasformazioni around the stylistic features of Giolito's Furioso. In the illustrations of the vernacular Ovid we therefore find the same pictorial effects, the same meaningful use of the perspective, and also the same elegant and sentimental representation of landscapes and human beings that were already present in the images for Ariosto's poem. ${ }^{7}$ On the other hand, the literary style of Dolce's translation is firmly based on the narrative and authorial solutions created by Ariosto. Therefore, in the vernacular version of Ovid we find again the use of the interlacement, which transforms the fifteen books of the Metamorphoses into the thirty cantos of the Trasformazioni; and we also find the imitation of Ariosto's pattern with the moralized beginning and the interruption at the end of every canto.

Analyzing the first pages of the cantos, we sometimes also find a very interesting case of dialogue between Ariosto's and Dolce's poems in the relationship between the main illustration, the illustrated initial (iniziale parlante), and the incipit. For the Trasformazioni, Giolito reused the same set

7. See Gerlinde Huber Rebenich, "L'iconografia della mitologia tra Quattro e Cinquecento. Edizioni illustrate delle Metamorfosi di Ovidio," Studi umanistici piceni 12 (1992): 123-33; Bodo Guthmüller, Mito, poesia, arte. Saggi sulla tradizione ovidiana nel Rinascimento (Rome: Bulzoni, 1997), 251-74; Ilaria Andreoli, "Fabulae artificialiter pictae: illustrazione del libro e decorazione ceramica nel Rinascimento," in Fabulae pictae. Miti e storie nelle maioliche del Rinascimento, ed. Marino Marini (Florence: Giunti, 2012), 111-25. 
of illustrated initial types (on Ovidian subjects) that decorated every proem of the Furioso. In some cases, the subject visualized by the illustrated initial can be thematically linked to the subject described in the text and represented in the main illustration. ${ }^{8}$ For example, Meleager's killing of the Calydonian boar is the same as the iconography of the main plate of the canto that narrates the killing of Pentheus turned into a boar (see figs. 2.1 and 2.2).

Besides anticipating the story of Meleager and the boar, which will be narrated at canto 17 , this small image probably also seeks to remind the reader of the incipit of canto 6 of the Furioso, marked by the same illustrated initial type and implicitly cited by Dolce's proem. There is an echo-effect, of sorts, between Ariosto's remark about Polinesso's evil trickery and Dolce's invective against the errant infidels:

\author{
Miser chi sollevar l'animo ardisce \\ là dove occhio mortal non corse avanti, \\ e la religion empio schernisce, \\ che già fondàr gli antichi padri santi; \\ che giusta sferza poi del ciel punisce, \\ se ben tarda a venir, sempre gli erranti, \\ come veggiamo a' nostri dì, e secondo \\ che vide spesso in molte etadi il mondo. (Dolce, Trasf. 17.1)
}

Miser chi mal oprando si confida

ch'ognor star debbia il maleficio occulto;

che quando ogn'altro taccia, intorno grida

l'aria e la terra istessa in ch'è sepulto.

E Dio fa spesso che 'l peccato guida

il peccator, poi ch'alcun dì gli ha indulto,

che se medesimo, senza altrui richiesta,

inavvedutamente manifesta. (Ariosto, Of 6.1)

8. See Franca Petrucci Nardelli, La lettera e l'immagine. Le iniziali 'parlanti' nella tipografia italiana (secc. XVI-XVIII) (Florence: Leo S. Olschki, 1991), 17-35; Françoise Glénisson-Delannée, "Illustration, traduction et glose dans les Trasformationi de Ludovico Dolce (1553): un palimpseste des Métamorphoses," in Le livre illustré italien au XVIe siècle. Texte/Image. Actes du Colloque organisé par le "Centre de recherche Culture et société en Italie aux XVe, XVIe et XVIIe siècles" de l'Université de la Sorbonne Nouvelle (1994), ed. Michel Plaisance (Paris: Presses de la Sorbonne Nouvelle, 1999), 119-47. 
Even more interesting is the relationship among the visual paratexts of the third and fourth cantos, because the representation of the first part of Phaeton's story (when the ambitious youth begs his father Helios to allow him to drive the flaming chariot) will be completed by the illustration of the fall of the inexperienced charioteer. The exemplary end of the story is visually underlined first by the small illustrated initial type and then by the main image of the fourth canto (see figs. 2.3 and 2.4).

The moral of the Ovidian myth is also epigrammatically expressed by Dolce in the first stanza through an alliterative nexus that links the keywords Folle-fallo-Fetonte (Foolish-Fault-Phaeton):

Folle chi sue forze non misura,

Ma temerario amante di se stesso

(Nebbia che l'occhio del giudicio oscura)

A far quel che non può si muove spesso;

Onde gli segue al fin danno e sventura,

Quando il fallo emendar non gli è concesso.

Ma pria ch'erga il pensiero, e troppo ascenda,

Da l'audace Fetonte esempio prenda.

[...]

E forse anch'io per questo mar audace

Sciolsi la vela del mio picciol legno,

Debile e poco di solcar capace

L'onda che pria varcò sì chiaro ingegno.

Ma mentre che di voi l'amica face

Fia di quest'alma tramontana e segno;

Non sol non temo il mio viaggio torto,

Ma spero gire a salvamento in porto (my emphasis).

(Foolish is the one who is not able to measure his strength and often tries to do what he cannot do; his reason has been obscured and he is like a superb lover of himself. At the end he suffers damage and bad luck, because the fault cannot be remedied. Therefore, before he sets his sights too high and rises too much, he has to follow the exemplum of brave Phaeton. [...] In the same way perhaps I, too, dared to hoist the sails of my little boat, which is fragile and unfit to face the waves that were first sailed by such a lively mind. 
But if your friendly torch will be leader and guide of my soul, I am not only not afraid to wander but also I hope to reach port safely [my emphasis])

Dolce also developed metalinguistically the meaning of the exemplary case of Phaeton, because he compares the ambitious flight of the Ovidian hero to his plan to translate such a classical masterpiece under the sign of Ariosto. Describing Phaeton's haughty flight, Dolce tries not only to translate Ovid but also to imitate Ariosto's poetry: the final metaphor of the poem as a boat trip is a clear allusion to the incipit of the last canto of the Orlando furioso, when the ship of the poem was received in the harbour by all of its readers ( $O f$ 46.1.1-2: "Or, se mi mostra la mia carta il vero, / non è lontano a discoprirsi il porto" [Now, if my map tells me the truth, the seaport is not too far]). A revealing mark of Dolce's literary strategy is represented by his re-use of the syntagma "di qua, di là" (this way and that way), which in Ariosto constitutes a stylistic embodiment of the collective madness denoted in the poem through the continuous wandering of the characters (my emphasis, below):

Come legno talhor, ch'onda marina

Solca, sgombro di quel che ritto il tiene,

Hor da quell'atto, hor da quell'altro inchina,

E senza 'l carco suo non può gir bene;

Così, poi che la guida sua divina

Il bel carro non preme e non ritiene,

Hor quinci, hor quindi via correndo s'alza,

Qual fosse vòto, e su per l'aria sbalza. (Trasf. 3.53)

Volge di qua di là la faccia mesta (Trasf. 3.59.1)

Ei, che di quello uscir vide il veleno,

$\mathrm{E}$ le ferite sue teme e paventa,

Fuor di se stesso, abandonò ogni freno,

Ché troppo il fiero assalto lo spaventa. (Trasf. 3.62.1-4)

E senza legge et ordine seguiro,

Poi non è chi gli freni, o 'ndietro volte:

Ch'ove gli porta l'impeto, a gran salti

Vanno fuor d'ogni calle, hor bassi, hor alti. (Trasf. 3.63.5-8) 
Dolce develops the metalinguistic feature of Phaeton's myth at the end of his poem too, as well as at the beginning of canto 17 (by comparing Hycarus with Phaeton), and at the beginning of canto 4, which is introduced by a large illustration of the falling chariot of the Sun. The long laudatory proem of canto 4 about contemporary writers (meaningfully compared to swans, as in Of 35.23.1-2: "Son, come i cigni, anco i poeti rari, / poeti che non sian del nome indegni" [As rare as swans are poets, poets worthy of this name]) is a kind of literary canon of his time and ends with Dolce's declaration of modesty with respect to his own poetry. Dolce describes his poetry as a lower fly in comparison with the poets previously celebrated (like Bembo, Sannazaro, Ariosto, Aretino, Contile, Caro, Varchi, Domenichi, B. Tasso, Giraldi Cinzio and others), but also marked by Phaeton's mad error (my emphasis, below):

Molti già furo, e a nostra etade ancora,

Magnanimo Signor, sono Fetonti,

Ch'ardiscon di poggiare ad hora ad hora

Deboli e infermi i più sublimi monti;

Onde avvien poi che 'n picciola dimora

Qual giù trabocchi e qual sciancato smonti;

E con vergogna sempiterna e danno

Riso e giuoco a' savi danno. (Trasf. 4.1)

Io, che poggiar di sì gran Cigni a paro

Non posso, humile Augel d'intorno a i liti

M'ergo con basso volo; e quindi prendo

I fior' di che quest'opra io vo tessendo. (Trasf. 4.12.5-8)

\section{Stanze nella favola di Venere e Adone}

A different case of the literary man-to-man combat between Dolce and Ovid (and, in this case, also with the "ghost" of Ariosto) can be found when comparing the translation of the Ovidian episode of Adonis in the Trasformazioni and the rewriting of the same story in Dolce's ottava rima poems Stanze nella favola di Venere e Adone. The content outline below clearly shows that in Dolce's Stanze the Ovidian plot has been altered to underline and develop 
the tragic dimension of the story of Venus and Adonis. ${ }^{9}$ The refashioning of the Ovidian plot (but also of the story narrated in the Trasformazioni) results both in an expansion of the narrative core of the myth as well as in a moralized summary of the related episodes of Myrrha and Atalanta. We can see above all that the indecent story of Myrrha, mother of Adonis, has been downgraded from a tale of first degree (like the one of Adonis) to a tale of second degree (like the one of Atalanta). When narrating the story of Atalanta, Venus tries to warn Adonis of Juno's cruelty. In the same way, Juno tries to convince Jove of the necessity of Adonis's death by explaining Myrrha's indecent passion for her father Cinyras.

\begin{tabular}{|l|l|}
\hline \multicolumn{2}{|c|}{ Ovid, Metamorphoses, 10.300-739 } \\
\hline $195 \mathrm{vv}$. & Story of Myrrha \\
\hline $30 \mathrm{vv}$. & Birth of Adonis \\
\hline $17 \mathrm{vv}$. & Love between Venus and Adonis \\
\hline $18 \mathrm{vv}$. & Venus warns Adonis \\
\hline $47 \mathrm{vv}$. & Story of Atalanta and Hippomenes \\
\hline $8 \mathrm{vv}$. & Death of Adonis \\
\hline $23 \mathrm{vv}$. & Planctus and metamorphoses of Adonis \\
\hline
\end{tabular}

9. On the Adonis myth and its refashioning in the Renaissance see Hélène Tuzet, Mort et resurréction d'Adonis: Étude de l'évolution d'un mythe (Paris: José Corti, 1987); Paolo Cherchi, "Molte Veneri e pochi Adoni (con un inedito attribuibile a G.B. Strozzi)," Esperienze letterarie 13.4 (1988): 15-38; Stefano Tomassini, "Adone a Milano, o una Venere per i Borromeo," Philo: logica 3.5 (1994): 26-69; Gianni Borgo, "Il mito di Adone nella cultura rinascimentale italiana," Levia gravia 2 (2000): 219-51; Anthony Mortimer, Variable Passions: A Reading of Shakespeare's Venus and Adonis (New York: AMS Press, 2000); Alessandro Grilli, Storie di Venere e Adone. Bellezza, genere, desiderio (Milan: Mimesis, 2012); Carlo Caruso, Adonis: The Myth of the Dying God in The Italian Renaissance (London: Bloomsbury, 2013); Alessandro Grilli, ed., Adone. Variazioni sul mito (Venice: Marsilio, 2014); Andrea Torre, "L’edonista riluttante. Erotismo, sessualità e mito adonico nel Rinascimento," Italique 17 (2014): 73-101. 


\begin{tabular}{|c|c|c|c|}
\hline $\begin{array}{l}87 \text { octaves } \\
(696 \mathrm{vv} .)\end{array}$ & $\begin{array}{c}\text { Stanze nella favola d'Adone } \\
\text { (1545) }\end{array}$ & $\begin{array}{l}85 \text { octaves } \\
(680 \mathrm{vv} .)\end{array}$ & $\begin{array}{l}\text { Le Trasformazioni } 21 \\
\text { (1553) }\end{array}$ \\
\hline $\begin{array}{l}1-3(24 \\
\text { vv.) }\end{array}$ & Proem & $\begin{array}{l}1-44(352 \\
\text { vv. })\end{array}$ & Story of Myrrha \\
\hline $\begin{array}{l}4-13(80 \\
\text { vv. })\end{array}$ & Locus amoenus & $\begin{array}{l}45-47(24 \\
\text { vv.) }\end{array}$ & Birth of Adonis \\
\hline $\begin{array}{l}14-25(96 \\
\text { vv. })\end{array}$ & $\begin{array}{l}\text { Love between Venus and } \\
\text { Adonis }\end{array}$ & $\begin{array}{l}48-50(24 \\
\text { vv. })\end{array}$ & $\begin{array}{l}\text { Love between Venus and } \\
\text { Adonis }\end{array}$ \\
\hline $\begin{array}{l}26-33(64 \\
\text { vv. })\end{array}$ & Venus warns Adonis & $\begin{array}{l}51-54(32 \\
\text { vv. })\end{array}$ & Venus warns Adonis \\
\hline $\begin{array}{l}34-47 \\
(112 \mathrm{vv} .)\end{array}$ & $\begin{array}{l}\text { Story of Atalanta and } \\
\text { Hippomenes }\end{array}$ & $\begin{array}{l}55-77 \\
(184 \mathrm{vv} .)\end{array}$ & $\begin{array}{l}\text { Story of Atalanta and } \\
\text { Hippomenes }\end{array}$ \\
\hline $\begin{array}{l}48-49(16 \\
\text { vv. })\end{array}$ & Venus goes away & & \\
\hline $\begin{array}{l}50-52(24 \\
\text { vv. })\end{array}$ & Juno and Jove & & \\
\hline $\begin{array}{l}53-63(88 \\
\text { vv. })\end{array}$ & Story of Myrrha & & \\
\hline $\begin{array}{l}64-70(56 \\
\text { vv. })\end{array}$ & Death of Adonis & $\begin{array}{l}78-80(24 \\
\text { vv. })\end{array}$ & Death of Adonis \\
\hline $\begin{array}{l}71-84 \\
(112 \mathrm{vv} .)\end{array}$ & $\begin{array}{l}\text { Planctus and metamor- } \\
\text { phoses of Adonis }\end{array}$ & $\begin{array}{l}81-87(56 \\
\text { vv.) }\end{array}$ & $\begin{array}{l}\text { Planctus and metamor- } \\
\text { phoses of Adonis }\end{array}$ \\
\hline 85 (8 vv.) & Motto & & \\
\hline
\end{tabular}

Let us first analyze the second degree tale of Atalanta and then, at a later stage, the tale of Myrrha. Some textual details of the Metamorphoses seem to create an allusive link between the characters of Hippomenes and Atalanta and Adonis. In the Trasformazioni, Dolce leaves out these details, but he does underline them in the Stanze. See, for example, the mention of the teenage appearance of Hippomenes, which clearly alludes to the anthropological 
archetype of a beautiful but fragile young man and finds its expression in the character of Adonis (my emphasis, below): ${ }^{10}$

Nec forma tangor (poteram tamen hoc quoque tangi),

sed quod adhuc puer est: non me movet ipse, sed aetas (Met. 10.614-15)

Trovossi a riguardar quella contesa

Hippomenés, un giovene gentile (Trasf. 21.60.1-2)

Un giovene gentile si trasse avanti

la cui bellezza e la tenera etate

Ne la donna crudel trovò pietate. (Stanze 37.6-8)

We can also point to the different translation of the Ovidian description of the handsome runner Atalanta, and especially to the detail of the movement of her wind-blown dress. In the Trasformazioni the erotic function of the gust of wind was more traditionally performed by Cupid, who shows Hippomenes Atalanta's blond hair and her body, while in the Stanze Dolce remains faithful to the Ovidian detail of the wind, even though he moves it from the first time Hippomenes met Atalanta to the moment of their race, i.e., to the situation that constitutes a sublimation of the sexual intercourse (my emphasis, below):

\author{
Aura refert ablata citis talaria plantis, \\ Tergaque iactantur crines per eburnea, quaeque \\ Poplitibus suberant picto genuali limbo, \\ Inque puellari corpus candorem ruborem \\ traxerat, haud aliter, quam cum super atria velum \\ Candida purpureum simulatas inficit umbras. (Met. 10.591-96)
}

10. See Anthony Mortimer, Variable Passions: A Reading of Shakespeare's Venus and Adonis (New York: AMS Press, 2000), 101: “The hermaphrodite figure is particularly relevant to Venus and Adonis because we already think of both protagonists in bisexual terms-Adonis as a hunter, proud of his male autonomy and yet feminine in his beauty and virginally fearful of sexual invasion; Venus as a woman inviting penetration, yet attracted by a beauty that, with its enticing hollows, casts her in the male role. What could be more fitting than that one doubly sexual identity should replace two split sexual identities and that sexual fusion should be the answer to sexual confusion." 
E mentre a gli occhi gli dimostra Amore

Il biondo crine, in cui feriva il vento,

E le carni, che tinge un bel rossore,

Qual suol purpureo vel coprire argento (Trasf. 21.63.1-4)

Giva la chioma de la bella testa

Sparsa e disciolta al vento, tremolante.

E 'l caldo, e 'l grato affanno, in ch'era avezza,

al bel volto rendea doppia bellezza.

La sottil gonna le sue carni ascose

A gli occhi di ciascun più non tenea

Di quel che 'l vetro suol vermiglie rose (Stanze 40.5-8; 41.1-3)

Dolce keeps representing Atalanta as an object of desire-as does the storyteller, Venus, of Adonis. If we look at the visual representation of the Adonis myth in the frescoes by Giulio Romano in the Palazzo Te in Mantua, it seems quite natural to link the beautiful pudenda of Atalanta, revealed by the wind, to the pretty white groin of Adonis escaping from the boar. One could probably find in these verses something of the erotic assault by the boar, which will be extensively and explicitly developed somewhat later by Giovan Battista Marino:

Fugge, ma 'l mostro innamorato ancora

per l'istesso sentier dietro gli tiene

ed intento a seguir chi l'innamora

per abbracciarlo impetuoso viene.

Ed ecco un vento al'improviso allora, se Marte o Cinzia fu non so dir bene, che per recargli alfin l'ultima angoscia gli alzò la vesta e gli scoprì la coscia. ${ }^{11}$

(Adonis runs away but the enamored beast follows him on the same path to hug him violently. And there a sudden gust of wind, induced by Mars or Diane to do evil to Adonis, lifted his dress and revealed his thigh.) 
Dolce's rewriting in the Stanze of the incestuous love between Myrrha and Cinyras-from which Adonis will be born-is much more interesting. He places the episode in the middle of the Stanze, just before the death of Adonis, and presents it as a story narrated in a very factious way by Juno to Jove. Playing as if they were at the court of the gods of Olympus, the "attorney" Juno delivers an uncompromising speech in which she tries to underline the reasons for Adonis's death, which Ovid instead presented as simply an accident (my emphasis, below):

At male conceptus sub robore creverat infans

quaerebatque viam, qua se genetrice relicta

exsereret ... (Met. 10.503-05)

Intanto il mal concetto fanciulletto

Homai d'ogni suo membro era perfetto (Trasf. 21.44.7-8)

Tu vedi, o sposo, s'è di viver degno

L'iniquo parto, il mal concetto seme

Ma d'empio seme horribilmente scesa

Del fier Plutone...

Con l'iniqua figliuola il padre giacque

E ingravidolla il seme ond'ella nacque.

(Stanze 64.1-2; 54.6-7; 60.7-8)

The tragic fate of Adonis's son seems to descend genetically from the indecent $\sin$ of his mother Myrrha. For that reason, Dolce prefers to translate the Ovidian sentence "male conceptus [...] infans" (badly conceived child) into the more scornful sentence "mal concepito seme" (badly conceived sperm). As a result, Dolce always remembers the sinful and guilty corporeality of Myrrha and her child, and presents her story as a "darkening pre-test for the tale of Venus and Adonis, which points to the perverse origins of desire." ${ }^{2}$ For 
Juno's summation, Dolce uses an accurate rhetorical strategy that consists of (1) the simplification of the Ovidian plot; (2) the omission of a psychological shade; (3) the moralization of the story; and (4) the persuasive argument for the prosecution. For that reason, starting from the beginning, Dolce marks Myrrha's behaviour as an obscene act that should be suppressed and forgotten, as Juno states at the beginning and at the end of her speech (my emphasis, below):

Dira canam: procul hinc natae, procul este parentes, aut, mea si vestras mulcebunt carmina mentes,

Desit in hac mihi parte fides, nec credite factum;

Vel, si credetis, facti quoque credite poenam (Met. 10.300-03)

Hora, quanto io dirò, Donne e Donzelle,

Lasciate d'ascoltar, e non leggete;

$\mathrm{O}$, se leggete pur, fra le novelle

E fra l'altre menzogne lo porrete.

O pur, se voglie tanto inique e felle,

Potesse Donna aver mai crederete,

Crediate ancor ch'ell'ebbe a parte a parte

Quel fin ch'io scriverò fra poche carte (Trasf. 21.3)

Anzi cotanto iniqua e scelerata

Ch'indarno lingua a raccontar si pone,

E 'ndarno cerca man spiegar in carte,

Del gran peccato suo la minor parte

[...]

Fugga ogni verginella intatta e pura,

Né sia da lei la brutta storia intesa

$[\ldots]$

Non lasciar che di lui ne resti segno:

Spegni quel corpo e la memoria insieme (Stanze 53.5-8; 54.3-4; 64.3-4)

The Changing Face of Ovid in Medieval and Early Modern Europe, ed. Alison Keith and Stephen Rupp, Essays and Studies 13 (Toronto: Centre for Reformation and Renaissance Studies, 2007), 223-38. 
Blaming Myrrha, Juno does not retain even the allegorical meaning given by Orpheus to the story (i.e., by the storyteller of all these myths in the Metamorphoses as well as in the Trasformazioni). Eurydice's unlucky lover urges his readers "to put no faith in this story and imagine it did not happen; or, if you do believe it, believe in the punishment, also, that is brought." In Dolce's Stanze, however, Juno seems to know very well that the literal signifier could be remembered together with the moral signified and so adopts a stronger line of censorship. She does not speak about Myrrha's moral doubts about her unnatural passion for her father, but prefers to describe her as a lustful nymphomaniac, not a young, anguished woman in love. Dolce's rewriting of the episode in which Myrrha tries to confess her forbidden desire to the nurse is a case in point. Both the sixty-two hexameters of Ovid's Metamorphoses and the eleven stanzas of Dolce's Trasformazioni describe how Myrrha is ashamed to admit the incestuous love to herself and to the nurse to the point that she begins to consider suicide; on the contrary, in one single stanza of the Favola (stanza 56), Juno underlines how impudent Myrrha is and how resolute in her will to carry out her obscene plan. Juno further explains that the nurse is unable to distract Myrrha from her perverted desire (my emphasis, below):

Illa quidem sentit foedoque repugnat amori

[...]

At virgo scit se non falsa moneri, certa mori tamen est, si non potiatur amore (Met. 10.319; 427-28)

Ben conosc'ella ancor che pecca et erra,

E più volte si danna e si riprende

[...]

Poi che ferma la trova, e 'n sul furore

Di pur morir, ebbe il piacerle caro (Trasf. 21.8.1-2; 29.5-6)

Star nel fier pensier mai sempre suole,

Et adempir le inique brame vuole.

Né sapendo sì come al sozzo fine

Del mal nato desio venir potesse,

A la baila, ch'avea canuto il crine,

Senza vergogna di scoprirlo elesse. 
Ella veggendo non poter al fine

Trarle del cor l'inique voglie impresse,

Ministra fu del scelerato effetto

Di por la figlia col suo padre in letto. (Stanze 55.7-8; 56)

Dolce translates Myrrha's consideration about the "laws of nature" using the same contracted mystification. In Ovid's Metamorphoses, Myrrha tries to justify her passion and make it understandable by appealing to the law of nature, which authorizes man and animals to make love without heeding to heteronormative impositions or parental taboos. As Marcel Detienne points out, this can be conceived as the "laws of Venus." ${ }^{13}$ In Dolce's Stanze, Juno calls upon the laws of nature in order to accuse Myrrha of not adhering to human reason, divine authority, and common law. But these are the "laws of Juno," the laws of a strictly ruled nature and a strictly governed society. Dolce underlines this fact by linking the three stories (Myrrha's, Atalanta's, and Adonis's). In the crucial moment of all these stories the hero becomes a pure object of desire and is represented as prohibited "flesh" offered to the lover-to the father Cinyras, to fated Hippomenes, and to the wild boar (my emphasis, below):

\section{1-3 [Atalanta]}

La sottil gonna le sue carni ascose

A gli occhi di ciascun più non tenea

Di quel che 'l vetro suol vermiglie rose

59.5-8 [Myrrha]

Così il misero padre nel suo letto

(Incauto, ché di ciò nulla sapea)

La notte ricevè de le promesse

La propria figlia, anzi le carni istesse.

69.1-6 [Adonis]

Ferì il Cinghial; ma poco il ferro immerse,

Che di fuor si mostrò lucido e netto.

Esso gli acuti denti empio converse

13. See Marcel Detienne, Les Jardins d'Adonis (Paris: Gallimard, 1972) and Pierangiolo Berrettoni, Il maschio al bivio (Turin: Bollati Boringhieri, 2007). 

A lui, che si smarrì nel vago aspetto;
E'l bel candido fianco tutto aperse
Con ampia piaga e lunga insino al petto.

We find other textual connections when Cinyras discovers his daughter's plot and begins to hunger for revenge. Myrrha finds a way to escape her father's fury not by way of the darkness of the night (as narrated by Ovid) but thanks primarily to her speed in running, which is also Atalanta's characteristic and, as Giulio Romano showed, that of Adonis as well. Dolce rewrites Ovid's plot with a dramatic editing that underlines, through repetition, the breach of a divine prohibition for the sake of an extreme passion (my emphasis, below):

Myrrha fugit tenebrisque et caecae munere noctis

intercepta neci est ... (Met. 10.476-77)

Quella pel buio de la notte occulta,

S'ebbe da quel furor divisa e sciolta (Trasf. 21.40.5-6)

Levar non pote, come volle, a lei

Con giusta man la scelerata vita,

Ch'ebbe al fuggir cosi veloci i piei

Ch'ei non la giunse ... (Stanze 62.1-4)

For this reason, too, when Adonis goes hunting and Venus leaves him alone, Dolce describes him as a sick person. The lively simile presents very well the pathological and queer frailty of Myrrha's child. On the one hand, Dolce refers to Adonis's unsuitability for fighting; on the other hand, he hints at Adonis's moral weakness when the youth falls into temptation as soon as he feels himself free from Venus's control. Dolce's simile could also be read as an allusion to the stanzas in the Furioso where Ariosto depicts Fiordispina, who shares her bed with her beloved Bradamante, like a "sick person flamed for passion" (my emphasis, below):

Sì come infermo, poi che gir lontano

Vedete chi di lui cura e ad altro attende,

Sopra il vietato frutto pon la mano, 
E trova alfin quel che l'annoia e offende;

Così 'l garzon [...] (Stanze 66.1-5)

Come l'infermo acceso di gran sete, s'in quella ingorda voglia s'addormenta, ne l'interrotta e turbida quïete, d'ogn'acqua che mai vide si ramenta; così a costei di far sue voglie liete l'imagine del sonno rappresenta.

Si desta; e nel destar mette la mano, e ritrova pur sempre il sogno vano. (Of 25.43)

Fiordispina is trying to sublimate in a dream her lesbian desire, which she had described before as more unnatural than the impious loves of Semiramis, Pasiphaë, and Myrrha, because all these passions were heterosexual, while the prohibition against Fiordispina's passion is a law of nature too strong to be breached. Quoting Ariosto's story of Fiordispina, Dolce aims at underlining the queerness of his hero. The problematic sexual status of Adonis is also suggested in the Stanze by references to Hyacinth, Ganymede, and Alexis, and by the fact that Adonis looks like Cupid's twin. The fact that Venus's lover can be seen as her son's twin and that his beauty has such a distinctly homoerotic appeal reminds us of all the ill-fated incestuous and homosexual passions that play such a large part in Ovid's Metamorphoses.

\section{The Cinque canti}

The last case of Ariosto's Ovidianism and Dolce's Ariostism we will briefly analyze is also an example of the stylistic and editorial relationship between word and image, and a paradigmatic explanation of the dynamics and strategies of reception in the early age of print. When the oral and written traditions of storytelling were still closely interwoven, the case of the narrative poem may be considered exemplary, because it put into circulation a literary heritage that made its influence felt first with books but then, by passing beyond the boundaries of the printed page, to a broader, illiterate public. This interweaving presents an interesting case of the vibrant mixing of "high" and "low" culture, and could have an unexpected learning function based on the close ties between 
reading, memory, imitation, and invention. The regular placement of images at the beginning of each canto of illustrated narrative poems is in line, for example, with a common book illustration strategy of mnemonic prolepsis and control of the act of reading that aims to invite the reader to search for that part of the text that best corresponds to the iconic anticipation.

Over the years the interest of the scholars for Ariosto's Cinque cantiour last literary and visual case study-focused mainly on its genealogical relationship with the Furioso and underlined the strongly dramatic tone of its representation of the chivalric world, which is very far from that of the Orlando furioso. ${ }^{14}$ Moreover, the status of the Cinque canti was perceived as problematic soon after its editio princeps by the Venetian printer Aldo Manuzio (1546). Was it the draft of a new poem that was supposed to be filled out and continue the story narrated in the Furioso? Was it conceived as poetic material that Ariosto would have placed here and there in the poem if he had had the time to do so? Was it a more or less cohesive and complete group of stanzas that was supposed to be attached at the end of the Furioso? The debate is lively because the history of the Cinque canti became not only a real editorial history, but also a history of book illustration. ${ }^{15}$

In the workshops of different printers, a parallel history evolved showing a mirroring between the two works that sometimes is due only to principles of formal and typographical economy, but often confirms precise politics of representation of Ariosto's poem (as a whole) and in some cases underlines (or reveals) a duplication of the narrative material between the Furioso and the Cinque canti. Sometimes the entire story is illustrated in a kind of competitive mimesis of the narrative content; in other cases a few episodes (or only one) have been selected in order to proleptically guide the reading and memorization

14. See Eduardo Saccone, “Appunti per una definizione dei Cinque canti," Belfagor 20 (1965): 381-410; Cesare Segre, Esperienze ariostesche (Pisa: Nistri Lischi, 1966), 121-77; Giorgio Padoan, "L'Orlando Furioso e la crisi del Rinascimento," Lettere italiane 27.3 (1975): 286-307; Marina Beer, Romanzi di cavalleria. Il Furioso e il romanzo italiano del primo Cinquecento (Rome: Bolzoni, 1987), 141-67; David Quint, "Introduction," in Ludovico Ariosto, Five cantos, ed. David Quint and Alexander Sheers (Los Angeles: University of California Press, 1996), 1-44; Sergio Zatti, "Introduzione," in Ludovico Ariosto, Orlando Furioso e Cinque canti, ed. Remo Ceserani and Sergio Zatti (Turin: Utet, 1997), 2:1633-51; Giuseppi Sangirardi, Ludovico Ariosto (Florence: Le Monnier, 2006), 218-29.

15. See Torre, "Illustrando i Cinque canti," in L'Orlando furioso nello specchio delle immagini, ed. Lina Bolzoni (Rome: Istituto della Enciclopedia Italiana, 2014), 227-62. 
of the text; finally, there is the suggestion that the printer decided not to create woodcuts ex novo to specifically represent a text but to reuse molds created for iconographic sets of similar episodes (in most cases woodcuts already used for the illustration of the Furioso).

In fact, the second edition of Ariosto's short poem published in 1548 by the Venetian printer Gabriele Giolito is characterized by textual variations and new verbal and iconic paratexts that give the Cinque canti the same editorial pattern adopted by Giolito for the Furioso from as early as 1542, which is also the same editorial pattern reused in 1553 for Dolce's Trasformazioni. Except for the illustration that opens the first of the Cinque canti in the 1548 Giolito edition, the other four images, all placed at the beginning of a canto, already appeared in Luigi Pulci's Morgante maggiore printed in Venice in 1546 by Comin da Trino. The image of the first canto emphasizes only the first episode, which is summarized in the first part of the allegory and underlined through capital letters: that is to say, the fairy council that sets the vicissitudes of the Carolingian army in motion (see fig. 2.5).

The strength of the representation is fully based on the suggestive juxtaposition of the supernatural flight of the fairies (carried by boats, imaginary animals, and demons) with the architectonic realism of Demogorgone's temple. The evocation of the highest level of artificial order through the geometry of the temple is functional also in the overall framework of the illustrations of Giolito's Cinque canti, since it makes us feel the chaos of human passions represented through the battle scenes illustrated in the other engravings as oppressive and indomitable. It seems, therefore, that Giolito carefully selected from the iconographic corpus of Pulci's Morgante the images that better illustrated Ariosto's fragment and then arranged them in a sequence that could be effective from a narrative perspective. From the second to the fifth woodcut, the spaces of the engravings are increasingly and confusingly filled with disjointed bodies and arms. It is more and more difficult to recognize the single characters of the heroes or to distinguish between the good and bad characters of the story. The dissolution of a virtuous architectonic rationality into the chaos of human passions is the iconographic representation of the progressive crisis of the chivalric and Renaissance values narrated in the Cinque canti, where we see how the actions of the characters are progressively guided by resentment and envy, and not by heroism and love. 
Starting in 1548, all the major illustrated editions of the Furioso are accompanied by an autonomous illustrated edition of the Cinque canti. In Valgrisi's edition of 1565 the project to visually represent all the events of Ariosto's poem through full page images is extended also to the fragment of the Cinque canti and also, in this case, by a perspective technique that guides the narration and defines its time of reading. It is important to note that the illustrations in this edition constitute the first completely original visualization of the Cinque canti (see figs. 2.6 and 2.7).

In the Cinque canti Valgrisi's illustrator also uses the representation technique already used in his visualization project of the Furioso from 1556 on, that is to say the reuse of figurative schemes from one engraving to the other. This technique duplicates with another expressive code the narrative entrelacement through which Ariosto links the different scenes of an episode, both in the case of scenes that belong to consecutive cantos as well as in the case of scenes far away from one another ${ }^{16}$ For example, Marfisa's overhanging attack, which dominates the foreground of the engraving for canto 4 , is a very detailed enlargement of the microscopic scene illustrated on the upper side of the engraving of canto 3 . Such a strategy helps the reader remember the unity and linearity of the main narration despite the digression in canto 4 dedicated to the story of Ruggiero and the whale (see fig. 2.8).

Going back to the first Valgrisi canto, we can see that the space is still mainly occupied by the representation of the fairy council, even if we can notice the effort to translate through images the entire content of the canto and above all the intrigues of Gano of Maganza, fomented by Alcina through the supernatural agent of Envy. As a link between the more popular scene of the magic council and the scenes dedicated to Gano's intrigues, Valgrisi's engraving illustrates an episode of the first canto that is of the utmost importance both for the narrative development of the fragment as well as, and above all, for the analysis of the critical consequences that the study of the illustrations has on the interpretation of Ariosto's work. This case clearly reveals how the visual mirroring conveys intertextual memory. In the first of the Cinque canti Alcina asks Envy to help her turn Gano of Maganza into an enemy of Carlo Magno. The literary source in Ariosto's episode of the meeting between Alcina and

16. See Serena Pezzini, "Il disegno dell'opera. Entrelacement e riprese nelle illustrazioni dell'Orlando Furioso edito da Valgrisi (1556)," in Le sorti d'Orlando. Il Furioso tra parole e immagini, ed. Massimiliano Rossi and Daniela Caracciolo (Lucca: Maria Pacini Fazzi, 2014), 117-42. 
Envy is Ovid's episode of the meeting between Minerva and Envy. Ariosto's rewriting of Ovid is both fine and precise. This illustration from the Cinque canti is also indebted to the iconography of the meeting between Minerva and Envy that appeared in Lodovico Dolce's Trasformazioni (See fig. 2.9).

From a textual perspective, while the Furioso reworks themes and episodes from Ovid's Metamorphoses, Dolce's “vernacularization" uses stylistic patterns derived from Ariosto's poem (my emphasis, below):

protinus Invidiae nigro squalentia tabo tecta petit: domus est imis in vallibus huius abdita, sole carens, non ulli pervia vento, tristis et ignavi plenissima frigoris, et quae igne vacet semper, caligine semper abundet. huc ubi pervenit belli metuenda virago, constitit ante domum (neque enim succedere tectis fas habet) et postes extrema cuspide pulsat; concussae patuere fores: videt intus edentem vipereas carnes, vitiorum alimenta suorum, Invidiam visaque oculos avertit; at illa surgit humo pigre semesarumque relinquit corpora serpentum passuque incedit inerti. utque deam vidit formaque armisque decoram, ingemuit vultumque ima ad suspiria duxit. pallor in ore sedet ... (Met. 2.760-75)

Fra i monti inaccessibili d'Imavo, che 'l ciel sembran tener sopra le spalle, fra le perpetue nevi e "l ghiaccio ignavo discende una profonda e oscura valle donde da un antro orribilmente cavo all'Inferno si va per dritto calle: e questa è l'una de le sette porte che conducono al regno de la Morte. [...]

S'accosta alla spelunca spaventosa, e percuote a gran colpo con un'asta 
quella ferrata porta, mezzo rósa

da' tarli e da la rugine più guasta.

L'Invidia, che di carne venenosa

allora si pascea d'una cerasta,

levò la bocca alla percossa grande

da le amare e pestifere vivande.

E di cento ministri ch'avea intorno,

mandò senza tardar uno alla porta;

che, conosciuta Alcina, fa ritorno

e di lei nuova indietro le rapporta.

Quella pigra si leva, e contra il giorno

le vien incontra, e lascia l'aria morta;

ché 'l nome de le Fate sin al fondo

si fa temer del tenebroso mondo.

Tosto che vide Alcina così ornata

D'oro e di seta e di ricami gai

(ché riccamente era vestir usata,

né si lasciò non culta veder mai),

con guardatura oscura e avenenata

gli lividi occhi alzò, piena di guai;

e féro il cor dolente manifesto

i sospiri ch'uscian dal petto mesto. (Cinque canti 1.38-42)

[Minerva] fiera si mosse,

Che d'ir a la caverna affumicata

(Poi che giusto disdegno la commosse)

De l'Invidia propose, e armata e sola

A l'albergo di lei s'indirizza e vola.

Giace in deserto e solitario loco

Una spelunca, ove non entra Sole

Né vento soffia, o vi s'accende foco.

Ma starvi il ghiaccio eternamente suole.

E'l lume che v'è dentro, è così poco

Ch'assembra inferno. Or quivi entrar non vuole

Palla, ma ne le porte, quanto puote,

Con la punta de l'hasta urta e percuote. 
Com'elle aperte fur, quell'empia vede,

Che si pascea di carni di Ceraste.

Pigra incontro a la Dea si leva in piede

L'Invidia, e lassa le vivande guaste.

Troppo l'aspetto fier conturba e fiede

De l'alma Dea le chiare luci caste;

Onde si volse a dietro. Ella sospira,

Quando'l bel viso e le ricch'arme mira. (Trasf. 5.37.4-39.8)

We can thus summarize the entire intertextual process in this way: Ariosto imitated an Ovidian text; Dolce translated this Ovidian text by taking Ariosto's imitation as a stylistic model; an accurate visualization of the materials from Ovid's Metamorphoses enriched Dolce's translation; finally, this image influenced the iconography of the illustrations in Valgrisi's edition of the Cinque canti that referred back to the Ovidian matter.

The examples of textual rewriting, translation, and visualization analyzed in this article can be conceived as a good confirmation of what Dolce said in the introduction to his version of Seneca's tragedy Thyeste, where he defined the art of translating a book as an experience that lives in the perspective of becoming "because in order to translate, it is necessary for us to take another language or (if possible) another human nature."17

17. Lodovico Dolce, Thyeste. Tragedia da Seneca (Venice: Gabriel Giolito de' Ferrari, 1547. sign. Ai ${ }^{\mathrm{r}}$ ) (my emphasis): “[...] molto più è da credere che difficile cosa sia lo esprimere o con parole, o con inchiostro i concetti d'altrui, di maniera che non si offenda né l'intelletto di chi gli legge, né l'orecchie di chi gli ascolta; percioché fa di mestiero che noi quasi un'altra lingua e quasi (se far si può) un'altra natura prendiamo. Non è dunque di sì poca importanza, come alcuni stimano, l'officio di tradurre un libro d'una lingua in un'altra in modo che si possa comportevolmente leggere" ([...] it is very hard to say or write the thoughts of another person in a way that do not offend reader's intellect and listener's hearing; in order to make a translation, it is for us necessary to take another language or (if possible) another human nature. It is therefore a challenging task to translate a book from a language to another so that it can be easily read). 


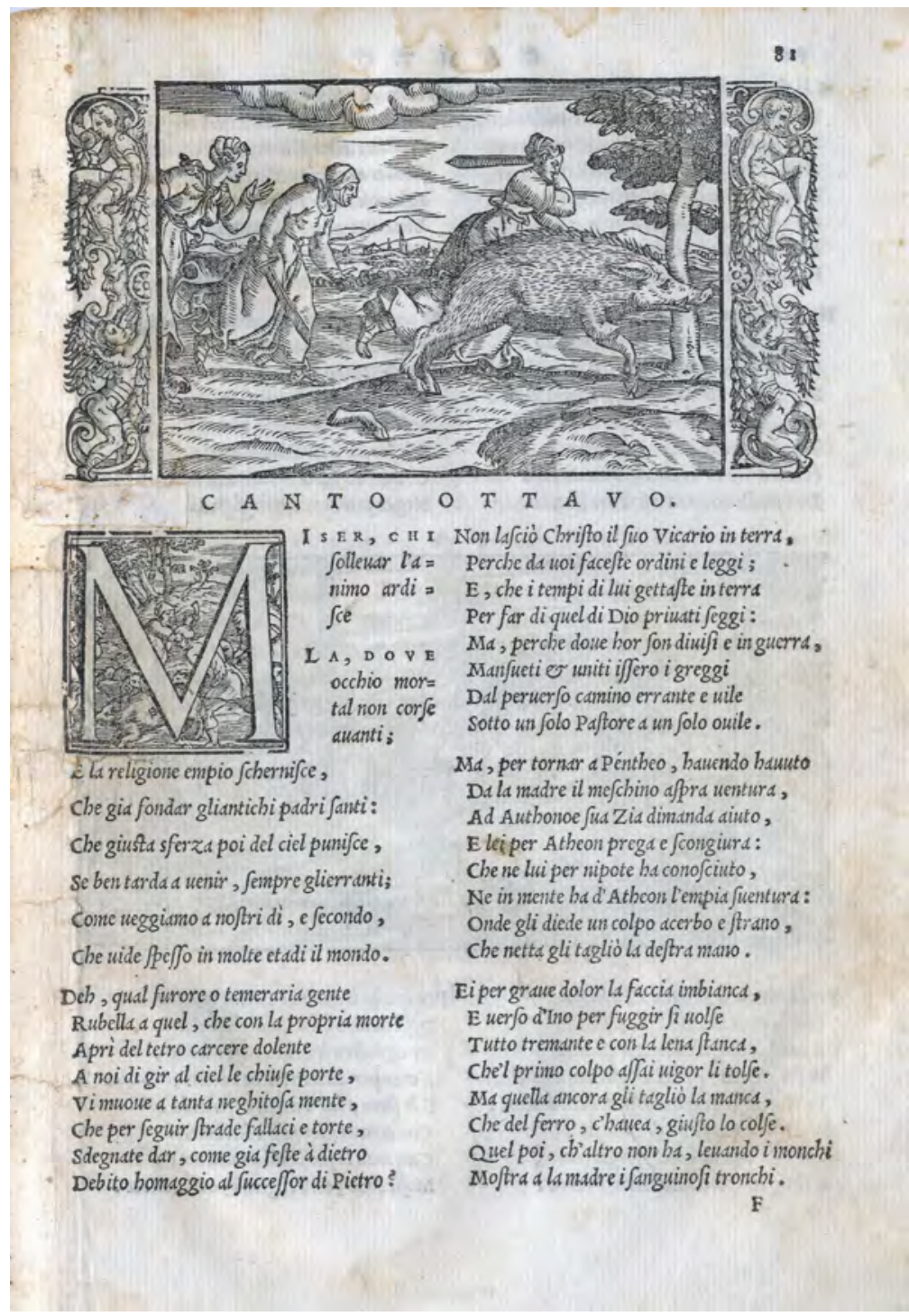

Figure 2.1. Lodovico Dolce, Le Trasformazioni, 8 (Venice: Gabriel Giolito de' Ferrari, 1555), fol. $81^{\mathrm{r}}$. (Biblioteca Comunale Panizzi, Reggio Emilia) 


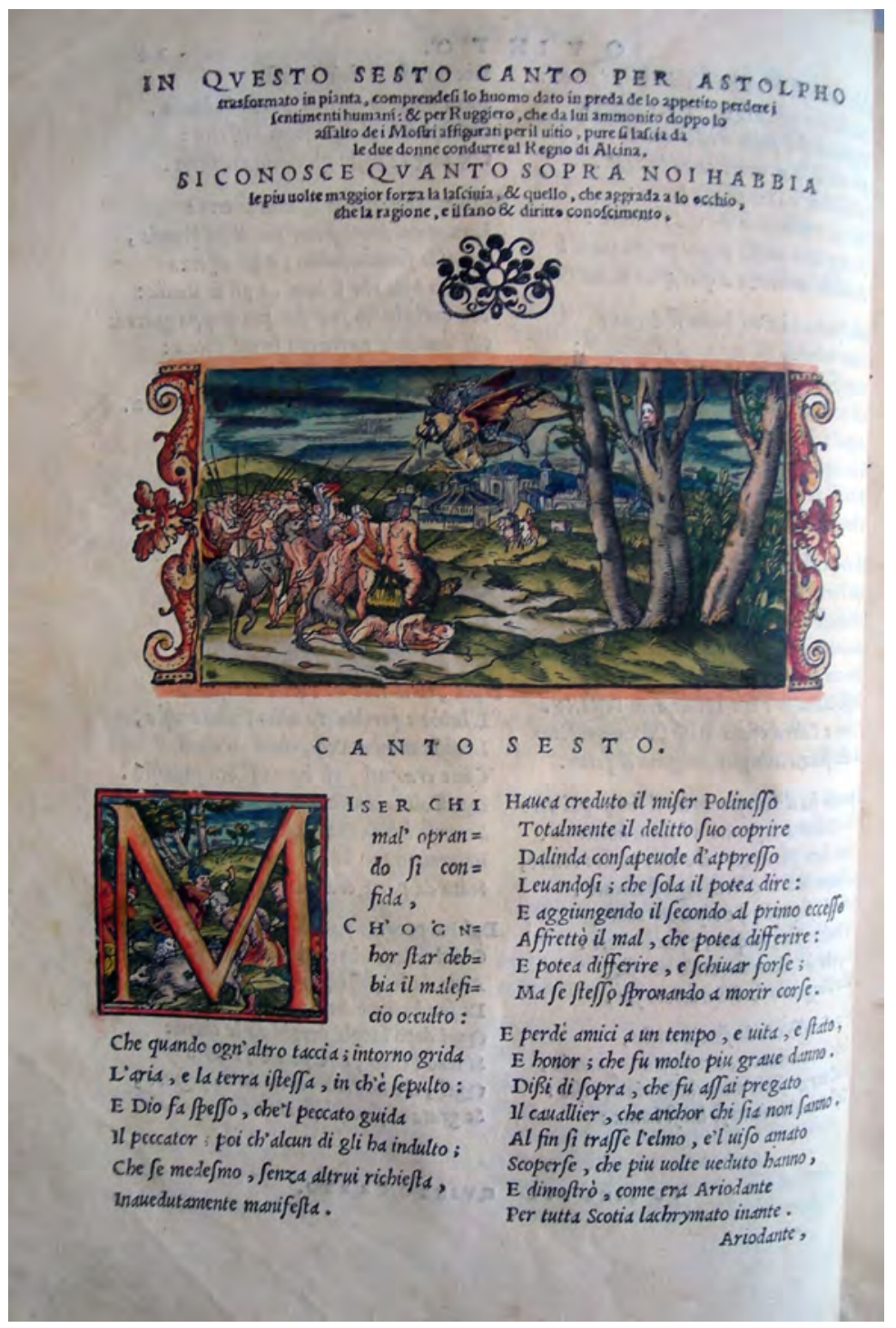

Figure 2.2. Ludovico Ariosto, Orlando furioso, 6 (Venice: Gabriel Giolito de' Ferrari, 1542), fol. 64v . (Biblioteca Nazionale Palatina, Parma) 


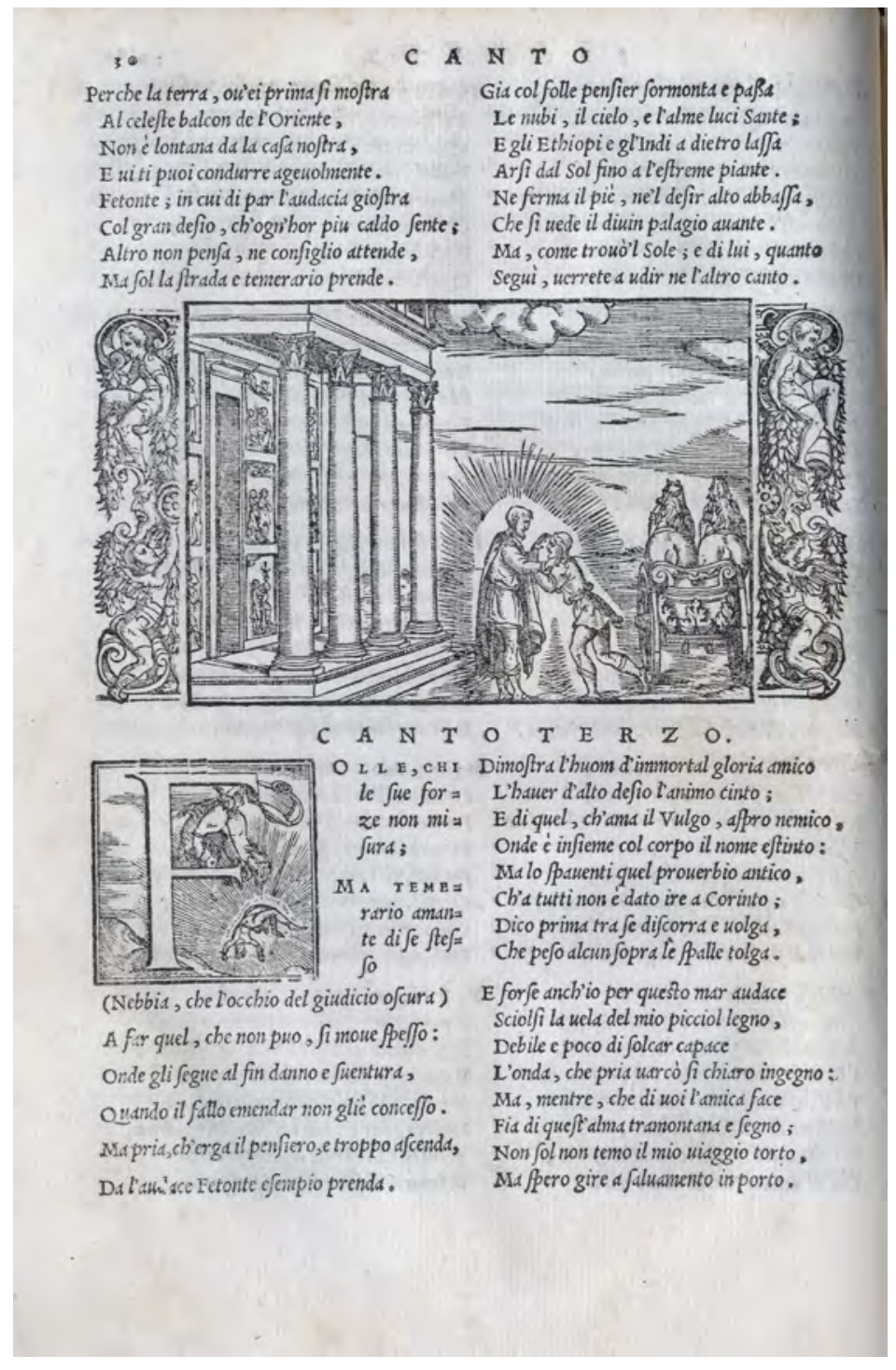

Figure 2.3. Lodovico Dolce, Le Trasformazioni, 3 (Venice: Gabriel Giolito de' Ferrari, 1555), fol. $30^{v}$. Reproduced by permission of Biblioteca Comunale Panizzi, Reggio Emilia. 


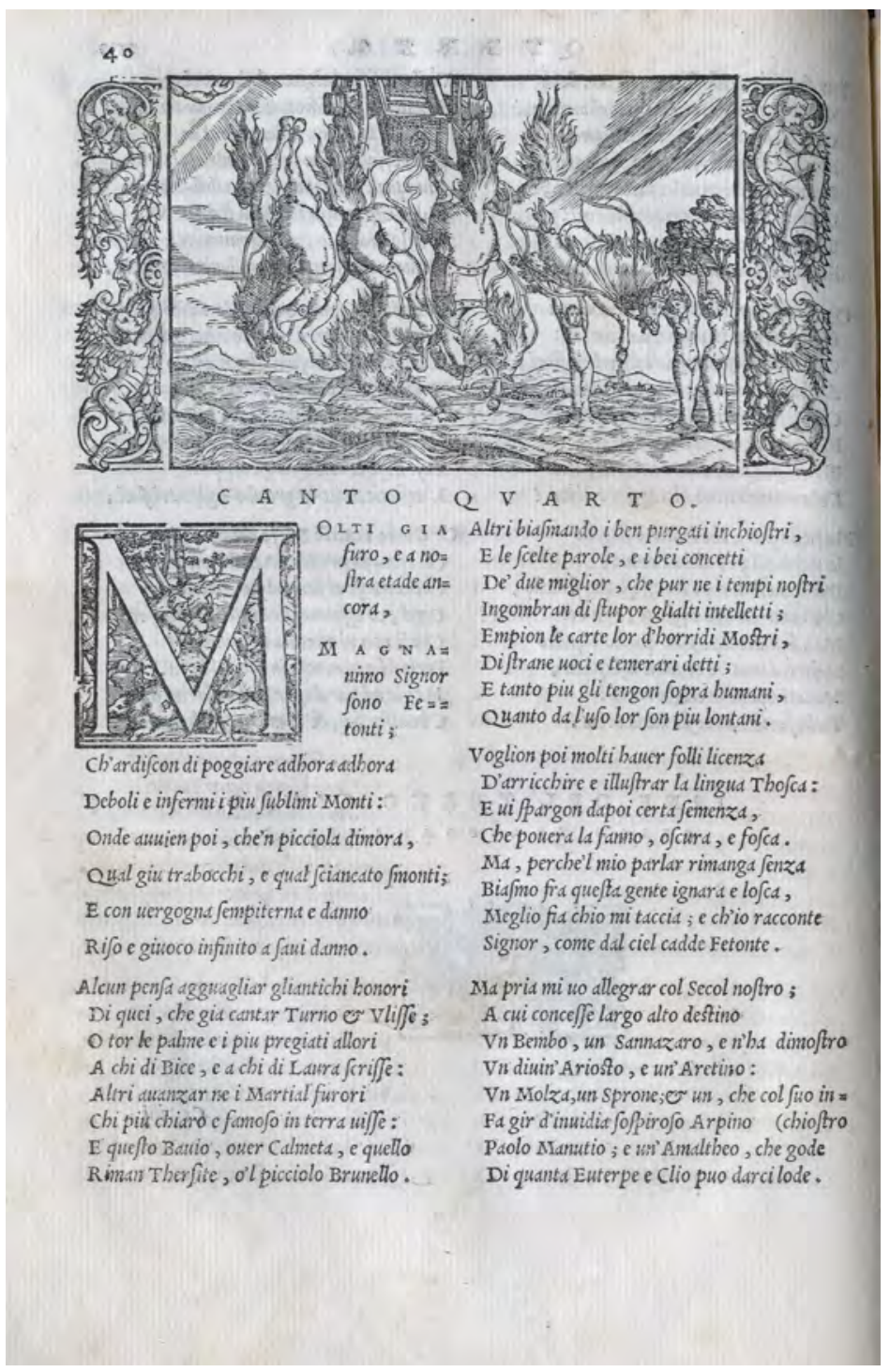

Figure 2.4. Lodovico Dolce, Le Trasformazioni, 4 (Venice: Gabriel Giolito de' Ferrari, 1555), fol. 40v . (Biblioteca Comunale Panizzi, Reggio Emilia) 


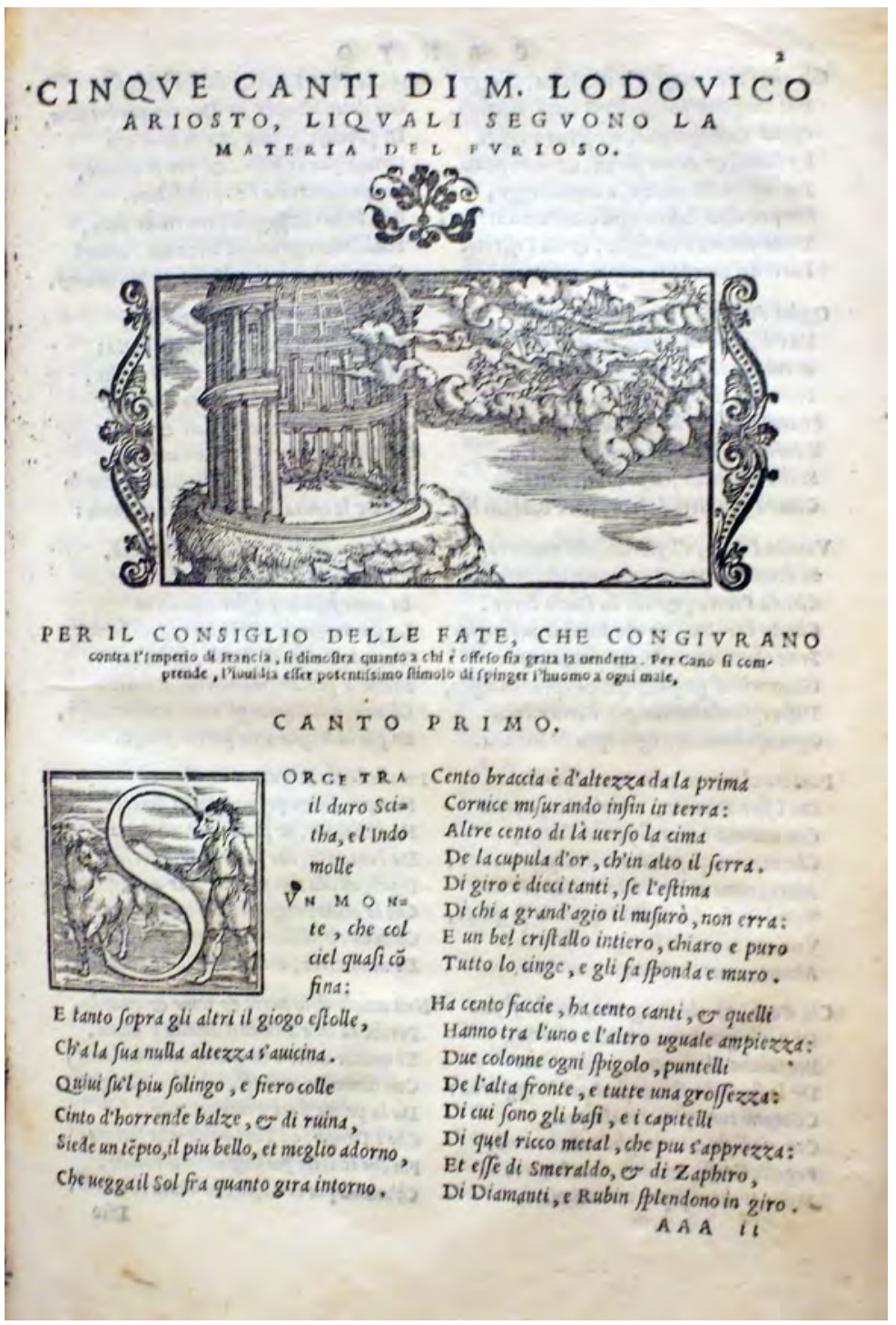

Figure 2.5. Ludovico Ariosto, Cinque canti, i quali seguono la materia del Furioso, 1 (Venice: Gabriel Giolito de’ Ferrari, 1550), fol. 271' ${ }^{\text {r }}$ (Biblioteca Comunale Passerini Landi, Piacenza) 


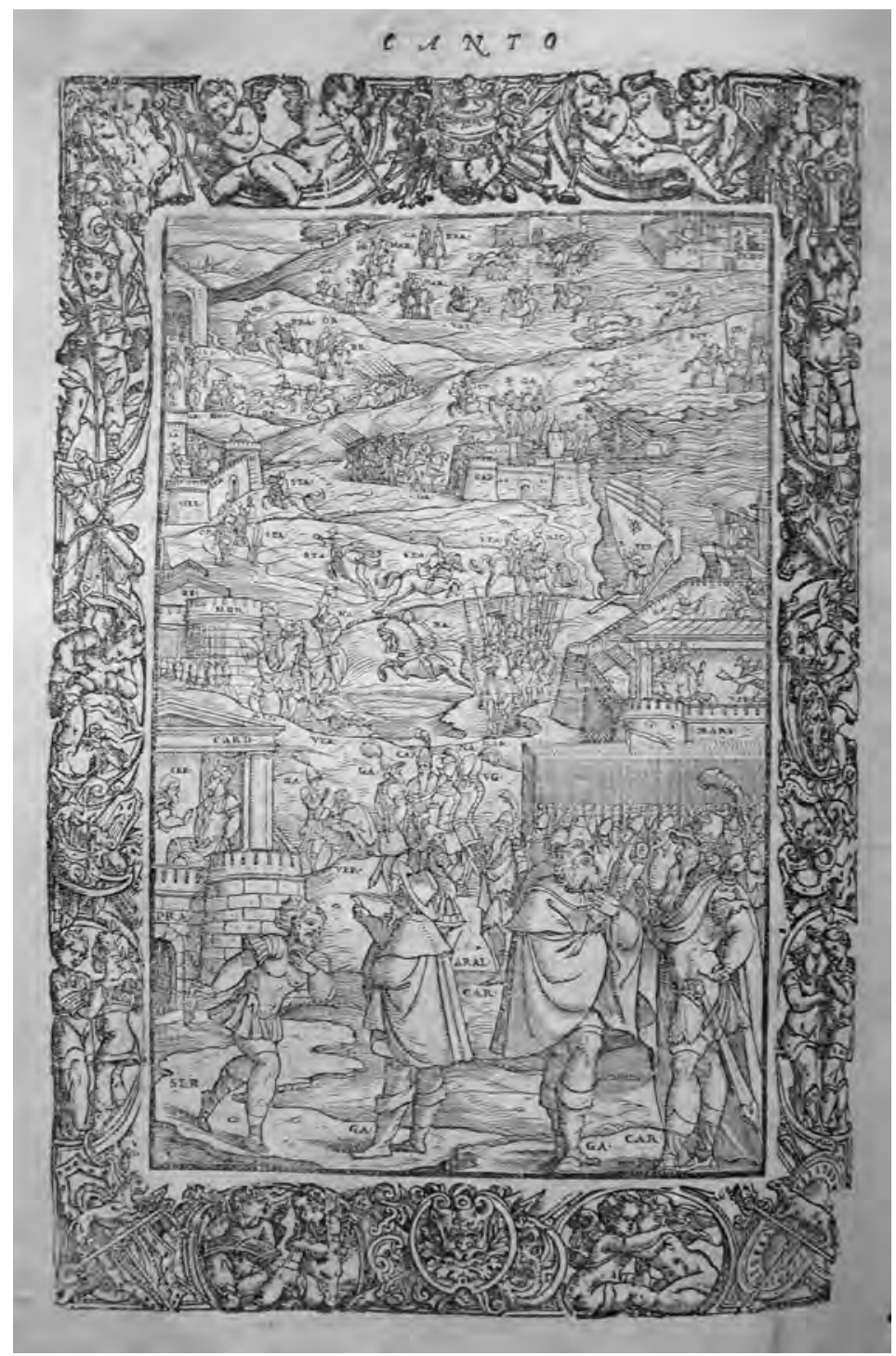

Figure 2.6. Ludovico Ariosto, Cinque canti, i quali seguono la materia del Furioso, 3 (Venice: Vincenzo Valgrisi, 1566), p. 518. (Biblioteca Comunale Passerini Landi, Piacenza) 


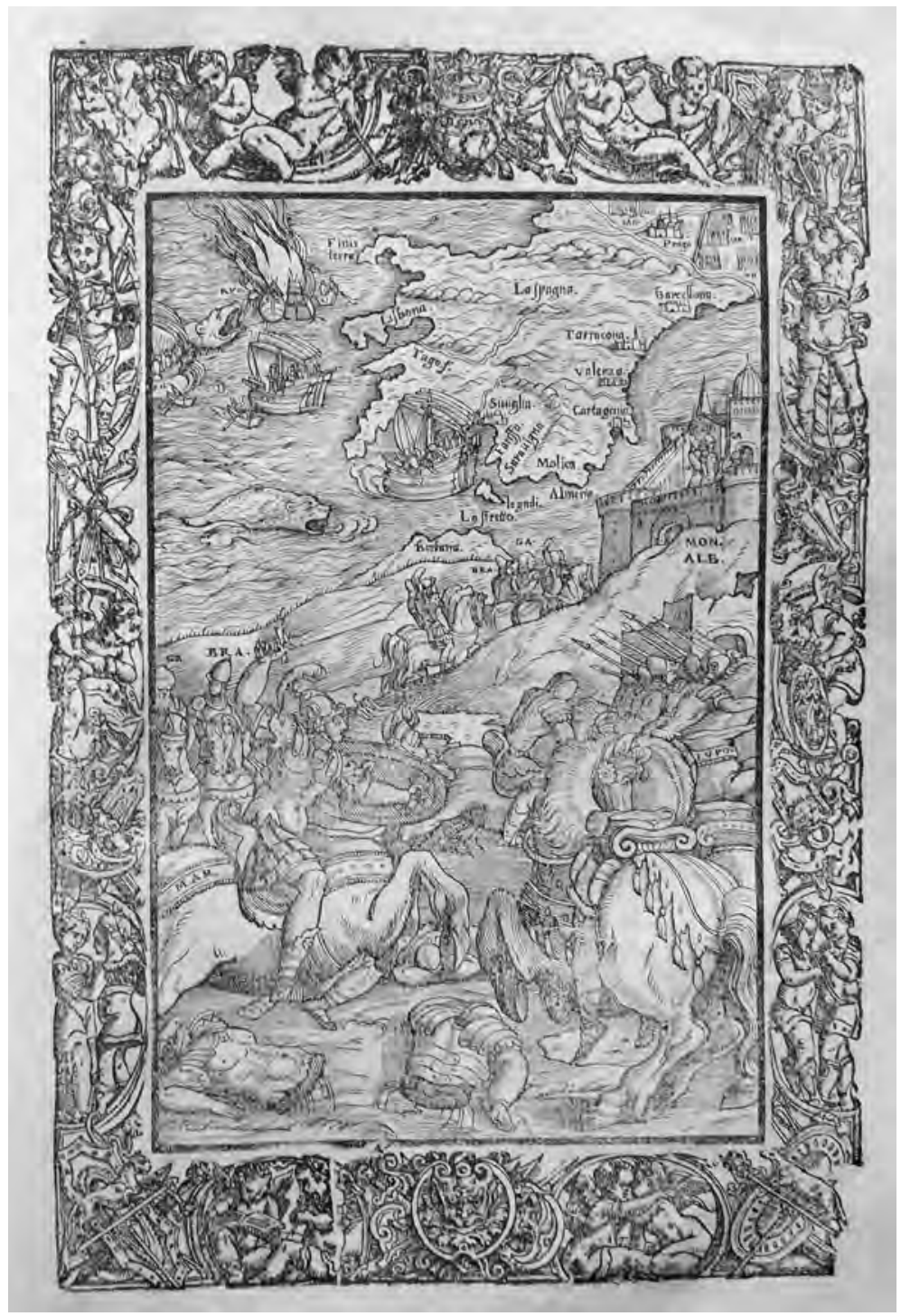

Figure 2.7. Ludovico Ariosto, Cinque canti, i quali seguono la materia del Furioso, 4 (Venice: Vincenzo Valgrisi, 1566), p. 528. (Biblioteca Comunale Passerini Landi, Piacenza) 


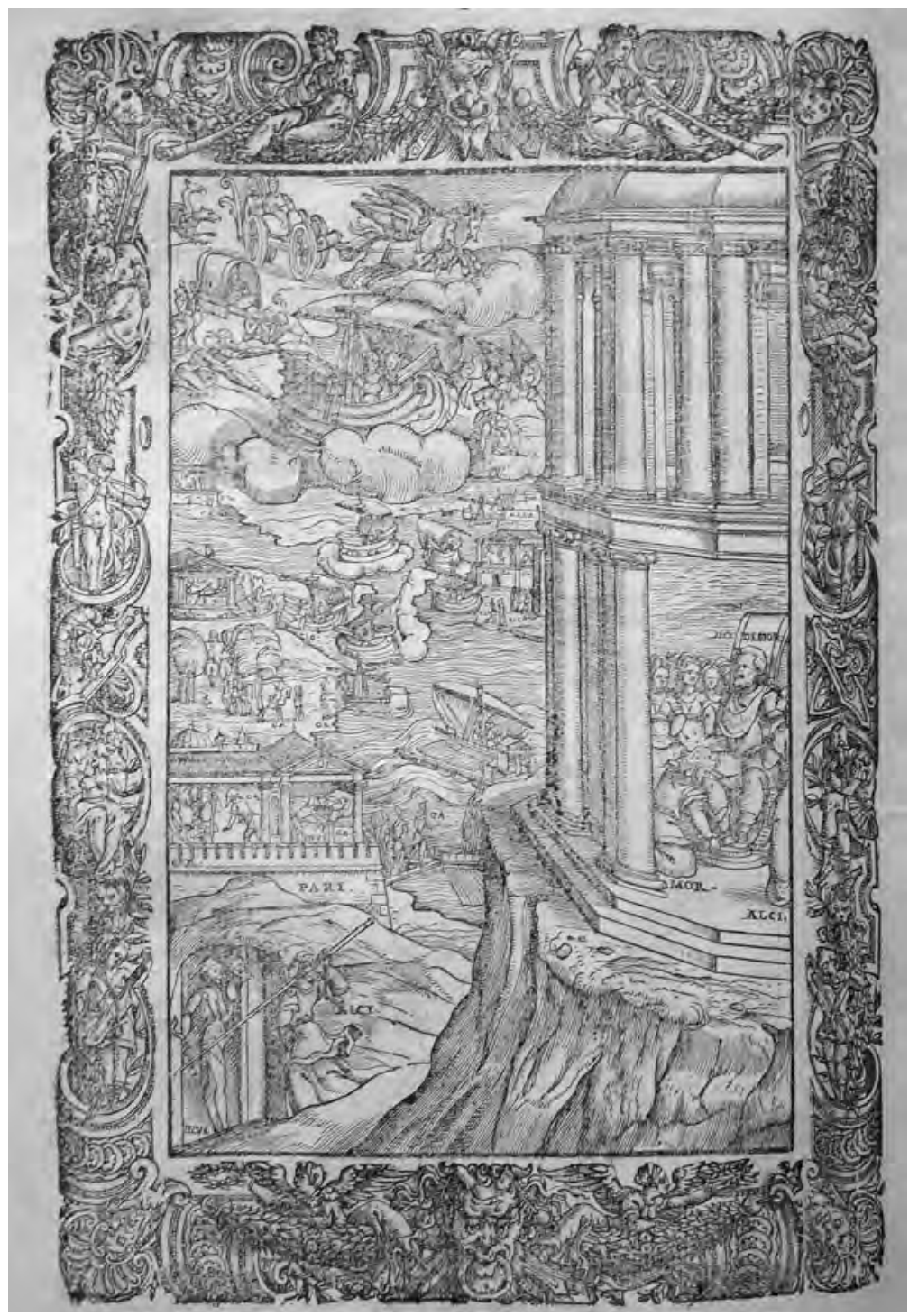

Figure 2.8. Ludovico Ariosto, Cinque canti, $i$ quali seguono la materia del Furioso, 1 (Venice: Vincenzo Valgrisi, 1565), p. 496. (Biblioteca Comunale Passerini Landi, Piacenza) 
56

Son del gran Gioue, egli ripoore, figlio, E de' Jegreti fuoi fido mejJaggio. Amo il bel uifo, e lamorofo ciglio D'Herfe, ch'e la cagion del mio uiaggio . Tu fola puoi col tuo fedel configlio Farmi gioir : che fpene altra non haggio. Ne ti dee (s'io non erro)effer difcaro D'acquiftar per cognato un Dio fi raro.

Aglauro con que gliocchi, ond' bebbe prid I egreti neduto di Minerua, Guardò Mercurio : e diffe, che faria Tutto quel, che puo fare amica e ferui, Con patto ueramente, che le dia (Altrimenti il contrario fi riferua) Vua gran forma d'Oro; e che le porte Sgombri; ne torni a lei fin che lo porte.
C A $\quad \mathrm{N}, \mathrm{T} / \mathrm{O}$

Con gliocchi torui a le parole wolfe La bellicofa Dea l'irato afpetto; E di quella dimanda ella fi dolje si, che le fcolfe alto fojpiro il petto . Ne la memoria poi fifo raccolje, Comella gia fprezzando il fuo precetto Ardiffe di mirar conl'occhio infano La brutta stirpe, il figlio di Vulcano.

Ne uolendo patir, ch'empia er ingrata A la Sorella or a Mercurio foffe ; E fi uedeffe mai ricca e beata Del dimandato don, fiera fi moffe; Che d'ir a la cauerna affumicata, (Poi che giusto disdegno la commo/fe) De l'Inuidia propofe : e armata e fola A l'albergo di lei s'indrizza e nola.
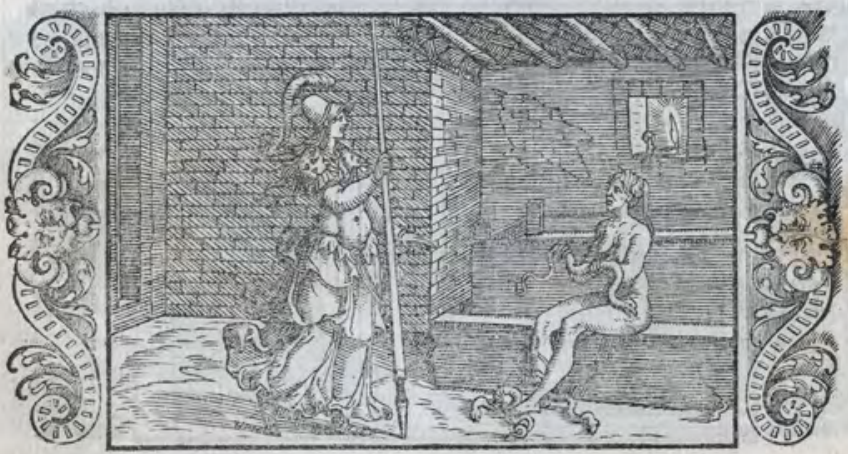

Gidce in deferto e folctario loco Via Pelunca; oute non entra Sole, Ne vento foffit, o ui s'accende foco, M.t farui il gbiaccio eternamente fuole. E'l liane, che t'é dentro, é cofi poco, $\mathrm{Cb}^{\prime}$ affembra Infrrio. Or quiui entrar nŏ unos P.llh; mit ne le porte, quanto puote, "Con la puita de lhastu urta e percuote.
Comielle aperte forr, queli'cnapia uede, Che fi paffect dicarni di Cerafte. pigra incontro a $4 \mathrm{De}$ fi leus in piede L'Inuidia, elaffa le viutande guafte. Troppo laspetto fier conturba e fiede De lalina Dea le cbiare luci caste; Onde fi wolfe a dietro. Ella fo/pira, Qumdo'l bel wijo e le ricchianne mira.

Figure 2.9. Lodovico Dolce, Le Trasformazioni, 5 (Venice: Gabriel Giolito de' Ferrari, 1555), fol. 56v. (Biblioteca Comunale Panizzi, Reggio Emilia) 